ks. Maciej Ostrowski

\title{
Turystyka drogą nowej ewangelizacji Europy
}

\section{Tourism as a way of new evangelization in Europe}

\begin{abstract}
Over the last decades, we have been witnessing in Europe a stronger and stronger influence of secularization and dechristianization. As these trends intensify, there is a need in the Church for more effective preventive measures described as new evangelization. It is usually defined as the search for new methods and means of expression in the Gospel message, corresponding to the mentality and ways of thinking of modern man. The article shows that the world of tourism can be such a space of new evangelization. In order for this evangelization to be effective, it is necessary to get to know and to understand the evangelical values of tourism. On the other hand, it is necessary to change pastoral methods and thinking in a number of areas.
\end{abstract}

Keywords: new evangelization, Europe, tourism, Christianity

Ostatnie dziesiątki lat jesteśmy w Europie świadkami coraz silniejszych wpływów laicyzacyjnych i dechrystianizacyjnych. W miarę nasilania się owych trendów w Kościele rodzi się potrzeba podjęcia skuteczniejszych środków zapobiegawczych. Streścić je można terminem nowa ewangelizacja. Coraz częściej mówi się nawet o potrzebie ponownej ewangelizacji albo wręcz reewangelizacji dotyczącej zwłaszcza krajów, które niegdyś były kolebką chrześcijaństwa, a dziś stają się w skrajnych przypadkach kolebkami walki z nim. Stolica Apostolska powołała oddzielną Papieską Radę ds. Nowej Ewangelizacji, a w 2012 r. odbył się się synod biskupów poświęcony tej sprawie. W artykule pragniemy wykazać, iż jednym z obszarów nowej ewangelizacji może stać się świat turystyki. Nawiązujemy do wskazań Papieskiej Rady ds. Duszpasterstwa Migrantów i Podróżnych, która zalicza turystykę do „nowych areopagów ewangelizacji, w których chrześcijanin ma przeżywać swoją wiarę oraz swoje misyjne powołanie” (Ostrowski red. 2003: 18). 
Nową ewangelizację zwykło się definiować jako poszukiwanie nowych metod i środków wyrazu w przekazie Ewangelii, odpowiadających bardziej mentalności i sposobom myślenia współczesnego człowieka. Dzięki odpowiedniemu ich doborowi Ewangelia skuteczniej dociera do człowieka i zdolna jest poruszyć jego serce oraz sumienie. W nowej ewangelizacji ważne jest obudzenie w Kościele nowej gorliwości w rozgłaszaniu Ewangelii i przekonanie, że wszyscy jego członkowie są za to dzieło odpowiedzialni. Swoje znaczenie ma zaangażowanie nowych podmiotów, zwłaszcza stowarzyszeń, ruchów i innych grup katolików świeckich. W naszym rozważaniu abstrahujemy od najistotniejszego czynnika poruszającego ludzkie serce, jakim jest Boża łaska. Działa ona w sposób obiektywny, znanymi tylko Bogu drogami. Niemniej ludzki czynnik w pewnym zakresie toruje droge Bogu i skłania człowieka do otwarcia się na Jego działanie. Najistotniejszym celem ewangelizacji jest osobiste spotkanie człowieka z Bogiem, otwarcie się na głęboką przyjaźń z Nim. Akt ten trudny jest do opisania w obiektywny i wyczerpujący sposób.

\section{1. „Język drogi”}

Człowiek współczesny, zwłaszcza Europejczyk, stał się człowiekiem niezwykle ruchliwym. Sprzyja temu niespotykany dotąd w historii rozwój komunikacji. Z drugiej strony rodzi się nowy styl życia. Ludzie chętnie odpoczywają poza swoim domem. Skłonni są pokonywać duże odległości, by uczestniczyć w rozmaitych wydarzeniach bądź spotkać się ze znajomymi. Z pewnością na ów styl istotny wpływ mają reklamy i wydawnictwa zachęcające do podróży i poznawania świata. Rozwojem tych trendów zainteresowany jest coraz lepiej prosperujący przemysł turystyczny. W krajach bogatszych, a do takich zalicza się znaczna część Europy, powstaje nadwyżka dóbr materialnych pozostająca po zaspokojeniu podstawowych potrzeb, która może być spożytkowana na uzyskiwanie wyższego rzędu dóbr, m.in. na turystykę. Stąd ,rodzi się" nowy typ człowieka, zwany niekiedy homo turisticus. Jego nowym językiem komunikacji jest „język drogi”. Ów język może stać się jedną z oryginalnych metod głoszenia Ewangelii, współgrającą z nową mentalnością. Zanim rozwiniemy zagadnienie, warto już w tym miejscu zauważyć, iż "język” ten koresponduje też z metodą charakterystyczną dla Chrystusa i Jego uczniów. Wszakże to On, a potem Apostołowie byli wędrownymi nauczycielami. Rozgłaszali Dobrą Nowinę częściej „w drodze” niż w stałych ośrodkach. Nie 
oczekiwali aż ludzie sami do nich przyjdą, ale wychodzili naprzeciw nich. Język ewangelizacji był od początku ,językiem drogi”.

Turystyka niesie ze sobą wielorakie wartości. Opisywane są one przez specjalistów różnych dziedzin (Ostrowski 1996). Nie jest naszym celem ich wyczerpująca eksplikacja. Natomiast postawmy pytanie, które z tych walorów w szczególny sposób mogą stać się nośnikami ewangelicznych wartości, a zatem sprzyjać ewangelizacji. Kolejny paragraf stanowi próbę ich wymienienia.

\section{Turystyka nośnikiem ewangelicznych wartości}

Turystyka sprzyja odnowie oraz rozwojowi ludzkiej osoby w różnych jej wymiarach: fizycznym, duchowym, religijnym i moralnym, indywidualnym i społecznym. Sobór Watykański II zachęcał, by wolny czas został „przeznaczony w sposób właściwy na relaks duchowy oraz wzmacnianie zdrowia ducha i ciała, tak przez zgodne z upodobaniem zajęcia i studia, podróże do innych krajów (turystyka), dzięki którym doskonalą się zdolności człowieka, a ludzie ubogacają się we wzajemnym poznaniu" (Gaudium et spes 1965: 61). Podczas swej wizyty w Nowym Targu w 1979 r. Jan Paweł II nawiązał do sytuacji turystów odwiedzających chętnie urocze górskie okolice. Mówił m.in.: „odpoczynek jest „poczynaniem na nowo... wypracowywaniem w sobie nowego stworzenia” (Jan Paweł II 1979). Człowiek, w myśl papieża, buduje nowość nie tylko w swym ciele, ale i w duchu. Turystyka ma być odpoczynkiem ciała, a bardziej jeszcze ducha.

Odnowy domagają się fizyczne siły człowieka. Wiele osób, zwłaszcza w okręgach miejskich, żyje w coraz bardziej zatrutym środowisku. Wzrasta tempo życia i ilość zajęć codziennych. Nasilają się stresy. To wszystko powoduje coraz poważniejsze zagrożenie dla ludzkiego zdrowia. Odbudowie fizycznych sił służy spędzanie czasu w sposób czynny i twórczy w turystyce, nie tylko na biernym wypoczynku, np. w postaci snu, wielogodzinnego oglądania telewizji lub przesiadywania w dusznych salach kawiarnianych. Turystyka uprawiana zwłaszcza w otwartych przestrzeniach, na łonie przyrody, ma szansę przekonania człowieka, iż jego życie oraz zdrowie są wielkim Bożym darem. Darem nie tylko osobistym, ale i społecznym. Dzięki dobremu zdrowiu i witalnym siłom człowiek może służyć lepiej i dłużej swojej rodzinie oraz całemu społeczeństwu. Nie staje się przedwcześnie niesprawnym rencistą i obciążeniem dla innych. Zdrowie należy rozumieć nie tylko w zawężonym do fizycznej sfery sensie. Jest ono harmonią wszystkich sfer ludzkiego 
życia: somatycznej, psychicznej, moralnej i duchowej, indywidualnej i społecznej. Co więcej, uwzględniającej ludzkie dążenie do celu ostatecznego (Häring 1963, Janik 2007). Zdrowym jest człowiek, który rozumie sens życia, a zarazem nie zszedł z drogi kierującej go ku ostatecznemu celowi egzystencji. Podczas turystyki otwiera się przed człowiekiem szansa osiągania tej harmonii.

Kontynuując myśl wskazaną przez Jana Pawła II, turystyka stanowi przestrzeń rekreacji ludzkiego ducha. Otwiera przed człowiekiem szansę „spotkania z samym sobą". Do jej istoty należy opuszczenie swego miejsca zamieszkania. Owo wyjście trzeba rozumieć nie tylko w sensie geograficznym. Polega ono także na oddaleniu od codzienności, oderwaniu od tego co na co dzień nas absorbuje i rozprasza, by móc docierać do innego rzędu wartości. Odpoczynek jest chwilą, w której człowiek znajduje spokój i ciszę, swoje własne „miejsce pustynne”, o którym mówił Chrystus do swoich uczniów (por. Mk 6, 31). Tam może usłyszeć „głos samego siebie”, a zarazem „usłyszeć rzeczywistość”. To pozwala mu zastanowić się nad sensem świata i swojego bytowania w nim, przywrócić równowagę ducha i odkryć głębię swojego człowieczeństwa. Tworzą się warunki sprzyjające kontemplacji ewangelicznych wartości. Taka przestrzeń staje się konieczna dla współczesnego mieszkańca Europy poddanego naciskom tempa życia, konkurencji i stresów z tym związanych. Narażanego zatem na niebezpieczeństwo zagubienia ostatecznego sensu swej egzystencji.

Docieranie do Boga i wytrwanie w wierze jest procesem trudnym. Wymaga ono pokonania niejednej ludzkiej słabości, hartu ducha i wytrwałości na modlitwie. Tych cech brakuje niejednemu współczesnemu człowiekowi - Europejczykowi nastawionemu na konsumpcję i wygodny tryb życia, żyjącemu wśród różnorakich ułatwień cywilizacyjnych. Trud związany z turystyką, pokonywanie przeszkód terenu, warunków pogodowych, a przede wszystkim swoich słabości, staje się dla chrześcijanina szkołą ascezy, wyrabia silną osobowość, gotowość do ofiar i wytrwałość, sprzyja opanowywaniu samego siebie i wewnętrznej dyscyplinie. W tym sensie turystyka może stanowić czynnik wspierający posuwanie człowieka w kierunku Boga.

Wiara buduje się i umacnia poprzez spotkanie z drugim człowiekiem. Najskuteczniejszym środkiem szerzenia Dobrej Nowiny jest świadectwo dawane przez chrześcijan. Tak działo się w czasach apostolskich i w kolejnych epokach historii Kościoła. Apostołowie byli wędrownymi głosicielami Chrystusa. Dawali o Nim świadectwo poprzez słowo i czyny. Turystyka z natury swojej prowadzi do spotkania z drugim człowiekiem (odwiedzane miejscowości, wspólnota wędrującej 
grupy). Międzyludzkie spotkania stają się okazją do wzajemnego świadectwa. Sobór Watykański II traktując o apostolstwie świeckich, przypomniał, iż wszyscy którzy „podróżują, czy to z racji załatwiania spraw międzynarodowych czy interesów lub wypoczynku, niech pamiętają, że wszędzie są wędrującymi głosicielami Chrystusa" (Apostolicam actuositatem 1965, n. 14). Swój wpływ na turystów mają także gospodarze odwiedzanych miejsc. Szczególnym jego przejawem jest chrześcijańska gościnność. Cnota ta była zawsze ceniona w chrześcijańskiej tradycji. Przywoływano jako przykład gościnność Abrahama (Rdz 18, 1-15, por. Hbr 13 ,1-2), Tobiasza (Tb 5, 4-22) i ewangelicznych sióstr Marii i Marty (Łk 10, 38-42), jak też słowa samego Chrystusa z mowy o sądzie ostatecznym (Mt 25, 35). W przybyszach przyjmowanych z miłością widziano samego Chrystusa. Dialog nawiązywany z drugim człowiekiem w turystyce staje się zatem okazja do ewangelicznej wymiany. Szansa takiego świadectwa istnieje ciągle w naszej Europie. Mimo rozlewających się szeroko wpływów laicyzacyjnych, wiele społeczności jest nadal nośnikiem autentycznej wiary. Ma zatem do zaofiarowania świadectwo wiary żywej, przejawiającej się na przykład w życiu sakramentalnym, modlitwie bądź dziełach miłosierdzia.

Turystyka prowadzi człowieka do spotkania ze światem natury. Naturalne środowisko samo w sobie jest nośnikiem fundamentalnych prawd o Bogu Stworzycielu. Jan Paweł II przyrównał przyrodę do „otwartej księgi”, w której odbija się przymierze Stwórcy ze swoim stworzeniem (Jan Paweł II 1985: n 14). W tej żywej księdze turysta odczytuje znaki obecności Boga. Obserwując harmonię i porządek przyrody, ma możność odkrywać cel stworzeń nadany im przez Stwórcę. Otwiera się na nadprzyrodzone rzeczywistości (Tourismus im Lichte christlicher.. 1986). W ciszy i pięknie przyrody, jak powiedzieliśmy wcześniej, znajduje stosowne środowisko do spokojnej refleksji nad sensem świata i swojej egzystencji. Mimo wzmożonej industrializacji, rozwoju ludzkich siedzib, rozbudowy infrastruktury komunikacyjnej zagarniającej coraz większe połacie ziemi, Europa zachowała wiele naturalnych zakątków. Mimo nacisków rozrastającej się materialnej cywilizacji obserwuje się w niej coraz mocniejsze trendy do ochrony przyrody i proekologiczną aktywność. Istnieje zatem szansa, że niewielki stosunkowo kontynent zachowa dziedzictwo natury z jej wychowawczymi walorami. Będzie nadal żywą „księgą przyrody”.

Turystyka stanowi niezastąpioną okazję do poznawania pomników chrześcijańskiej kultury i religijnych zwyczajów. Można zaryzykować stwierdzenie, iż znakomita część celów turystycznych podróży to obiekty sakralne: sanktuaria, kościoły, 
nekropolie bądź muzea religijne. W większości regionów Europy, zwłaszcza zamożniejszych, otaczane są one troskliwą opieką konserwatorów sztuki, w mistrzowski sposób restaurowane, stając się perłami kultury. Sobór Watykański II podkreśla, iż sztuka religijna, a zwłaszcza sakralna „nastawione są na nieskończone piękno Boże i mogą skutecznie zwracać ku Bogu ludzkie serce" (Constitution on the Sacred Liturgy... 1963, n.122). Podziwiając twory chrześcijaństwa, turysta ma okazję odczytywać liczne znaki wyrażające w sposób plastyczny prawdy wiary i historię zbawienia. Nie na próżno wystrój wnętrz świątyń jest nazwany biblia pauperum. Religijnym duchem przeniknięte są tradycje i zwyczaje pielęgnowane przez lokalne społeczności. Wszystko to stanowi specyficzny język ewangelicznego przekazu. Europa budowała swe korzenie na chrześcijaństwie. Na każdym kroku w jej kulturze materialnej i niematerialnej znajdujemy znaki religijności. Nie możemy się tego wstydzić, ani pomijać milczeniem. Ale z drugiej strony nie możemy ich sprowadzić tylko do martwego skansenu. Niestety wiele wskazuje na to, iż obiekty religijnej kultury nawet przez samych chrześcijan pozbawiane są wyrazu żywej wiary i są nośnikami jedynie „pamięci chrześcijaństwa” (Jan Paweł II 2003). Świadczą o tym choćby tłumy turystów zadeptujących kościoły, nie wykazujące poczucia sacrum. Jednak mimo zewnętrznych pozorów w wielu regionach wskazane twory chrześcijańskiej kultury nie są tylko obiektem muzealnym. Wciąż pozostają w dynamicznym związku z życiem Kościoła, liturgią i modlitwą. Tętni w nich religijne życie. Noszą w sobie zatem znaczący ewangelizacyjny ładunek.

\section{Turystyka religijna}

Ostatnie dziesiątki lat jesteśmy świadkami rozwoju gałęzi turystyki określanej mianem turystyki religijnej. Dynamicznie rozwijają się na przykład szlaki chrześcijańskiej kultury ${ }^{1}$. Łączy ona w sobie wątki poznawcze i wypoczynkowe z religijnymi. Plasuje się pomiędzy klasyczną turystyką a pielgrzymką. Pierwszorzędnym jej celem nie jest udział w kultycznych aktach. Jej uczestnicy zainteresowani sa

1 Wymieńmy przykładowo szlaki Jana Pawła II w wielu rejonach Polski, Szlak Architektury Drewnianej w Małopolsce i na Podkarpaciu łączący w znakomitej części obiekty sakralne, w ostatnich latach poszerzany na stronę słowacką, gdzie w wielu regionach nosi piętno bardziej kulturowe niż pielgrzymkowe, Szlak zadumy chrześcijańskiej w Beskidzie Małym, Papst Benedikt Weg w Bawarii, Gründerweg von Aflenz-Kurort nach Mariazell w Styrii, słynną Drogę św. Jakuba do Santiago. 
zasadniczo chrześcijańską kulturą, odwiedzają sakralne obiekty, podziwiają dzieła religijnej sztuki. Przy tej jednak okazji włączają się w wybrane nabożeństwa (Ostrowski 2002).

Turystyka religijna nosi w sobie szczególną ewangelizacyjną szansę. Same odwiedziny miejsc związanych z religią wprowadzają człowieka w sferę sacrum i w naturalny sposób kierują ku rzeczywistości nadprzyrodzonej. Zwróciliśmy uwagę na tę sprawę wcześniej. Turystyka religijna ma szansę przyciągnięcia osób o słabszej wierze, a nawet niewierzących, ze względu choćby na prostą ciekawość. Pielgrzymka może stanowić dla nich formę zbyt wymagającą i zniechęcająca. Łatwiej zaprosić ich na wędrówkę, w której program będą wkomponowane religijne elementy. Umiejętnie prowadzona tego rodzaju wycieczka pozwoli na powolne, ciche oddziaływanie religijne. Może stwarzać liczne okazje do ewangelicznego świadectwa. Staje się swoistego rodzaju dialogiem, zarówno werbalnym jak i niewerbalnym z człowiekiem o słabej religijności. W ten sposób otwiera się szansa ewangelizacyjnego oddziaływania na turystę.

Krótki przegląd sytuacji związanych z turystyką przekonał nas, iż w może ona mieć ewangelizacyjne walory. A zatem może przyczyniać się do pogłębiania więzi człowieka z Bogiem. Dla osób stających z dala od wiary jest szansą powrotu do niej.

\section{Duszpasterskie implikacje}

W ostatniej części artykułu zwróćmy uwage na duszpasterskie inicjatywy, które powinny zostać podjęte, by turystyka stała się rzeczywiście drogą nowej ewangelizacji. Zarazem zwrócimy uwage jak należy kształtować duszpasterstwo, by skutecznie realizowało swe zadania w świecie turystyki.

Duszpasterstwo turystyczne powinno być z zasady duszpasterstwem drogi. Ujmując inaczej, samo ma być „w drodze”. W szeregu wypadkach będzie ono w tradycyjny sposób zapraszać turystów-gości do skorzystania z tradycyjnych posług ofiarowanych przez parafie bądź inne stałe duszpasterskie ośrodki. Powinno jednak w znaczniejszym stopniu wychodzić poza stałe siedziby, być w drodze z turystami, towarzyszyć ich podróży. Jak łatwo zauważyć, w samym owym wyjściu zawiera się rys ewangelizacyjny. Apostoł-ewangelizator nie pozostaje „w domu”, ale wychodzi na drogi, poszukuje na nich człowieka. Wzorem stał się sam Chrystus, który wędrował przez miasta i wsie, nauczając i głosząc Ewangelię (Łk 8, 1). Szczególnie wymowne stało się jego nauczanie w drodze 
do Emaus, gdy wyjaśniał uczniom proroctwa i późniejsze wydarzenia, a w końcu doprowadził do poznania prawdy o zmartwychwstaniu (Łk 24, 13-27). Diakon Filip wykładał Pisma dworzaninowi etiopskiemu podczas podróży na wozie i tak doprowadził go do wiary. Także jego chrztu dokonał w przygodnym strumieniu (Dz 8, 25-38). Wędrownym ewangelizatorem był św. Paweł i inni apostołowie.

Turystyka polega na ruchu, wyjeździe poza rodzinny dom. Turysta korzystając z wolnego czasu, chce oderwać się od codzienności, poznawać świat i szukać dogodnego miejsca wypoczynku, poza obszarem zwyczajnej pracy i obowiązków. Tam właśnie duszpasterstwo ma być z turystą, pomagać mu w postrzeganiu świata chrześcijańskimi oczami, wskazywać jak trzeba w tym samym duchu korzystać $z$ wypoczynku. Nie jest to jednoznaczne $z$ instruowaniem na temat sposobów wypoczynku. Zrobią to lepiej specjaliści od rekreacji. Natomiast należy uświadamiać ludziom, iż wolny czas winien uwzględniać dążenie do wyższego rzędu wartości. Jest on także obszarem chrześcijańskiej odpowiedzialności. Pełny odpoczynek to nie tylko wypoczynek ciała, ale rekreacja ducha. Uwzględnia ona, jak powiedzieliśmy wcześniej, refleksję nad sensem swego życia i chwile na spotkanie $z$ Bogiem. Stąd $w$ turystykę ma wpisywać się harmonijnie religijne świętowanie (zwłaszcza świąteczna msza św.).

Jak zauważyliśmy, turyści chcąc odpocząć odchodzą od codziennych spraw. Nierzadko jednak równocześnie porzucają tradycyjny rytm udziału w nabożeństwach (zwłaszcza niedzielnej mszy św.). Sytuacja ta może budzić zgorszenie. Warto jednak zastanowić się nad niejednoznacznymi przyczynami absencji. Z pewnością głęboko wierzący będzie wszelkimi sposobami szukał możliwości udziału w niedzielnej mszy. Niekiedy jednak oddalenie od ośrodków religijnych staje się przeszkodą trudną do pokonania. To stawia przed duszpasterstwem pytanie, czy z tą mszą św. nie należy wyjść poza parafialny Kościół, tam gdzie znajdują się skupiska turystów. Niekiedy wystarczy lepsze dostosowanie godzin odprawiania mszy św. do rytmu życia turysty (wczesne lub późne godziny dnia, msza św. w sobotę wieczorem). Tu znów pojawia się wątek ewangelizacyjny - poszukiwania niekiedy zagubionego człowieka. Autor artykułu wielokrotnie spotykał się z sytuacją, gdy pewne grupy osób nie przychodziły na mszę św. parafialną, natomiast skłonne były uczestniczyć w tym samym dniu w mszy św. polowej, w górach, wśród przyrody. Można oczywiście podjąć krytykę takich postaw. Z drugiej jednak strony fakt chęci uczestnictwa w nabożeństwie polowym był znamienny. Świadczył mimo wszystko o potrzebach duchowych tych katolików „z marginesu”. Rodzi 
się zatem pytanie: czy nie warto pójść za tymi słabiej wierzącymi i dotrzeć ze słowem Ewangelii tam gdzie jeszcze istnieje z nimi kontakt?

$\mathrm{Z}$ podobnych przyczyn poszukiwania człowieka w drodze warto organizować religijne przeżycia na turystycznym szlaku (msze św., nabożeństwa), wśród turystów: podczas ich rajdów, zlotów i tym podobnych obchodów. Jest to okazja do pokazania, iż imprezy te będą przeżywane w bogatszy i głębszy sposób, gdy odniosą człowieka do Boga, gdy posłucha on słów Ewangelii, które zinterpretują jego bieżące przeżycia z chrześcijańskiego punktu widzenia.

Duszpasterstwo drogi, jak się zdaje, wymaga zmiany sposobu myślenia samych duszpasterzy i kościelnych przełożonych. Dla niektórych może być to swoistego rodzaju rewolucją. Można wyjść od interpretacji ewangelicznego obrazu pasterza poszukującego owiec (Mt 18, 12-14). Powstaje pytanie, czy to owce mają szukać pasterza, czy pasterz owiec? Sytuacja współczesnego Kościoła gwałtownie zmienia się. Trzeba się liczyć z faktem, iż wiele z owiec nie przyjdzie już na wołanie pasterza, nie zjawi się w parafialnym kościele. To pasterz ma wyjść i poszukiwać zagubionych. Stawać się bardziej mobilny, stawać do dyspozycji owiec. Autor ośmieli się użyć stwierdzenia: stawać się bardziej ewangelizacyjnym. Jest to poszukiwanie człowieka ulegającego coraz bardziej dechrystianizacyjnym wpływom. Przekłada się to w świecie turystyki na konkretne rozwiązania. Dodajmy do wymienionych już wcześniej: gotowość do poświęcenia części swojego kapłańskiego urlopu, by posłużyć turystom, gotowość do towarzyszenia na im szlakach, w okresach sezonu turystycznego przesunięcie duszpasterskich sił z pustoszejących miast do regionów gdzie nasila się turystyczny ruch, by pomóc obciążonym tam duszpasterzom². Tu przypomnijmy stwierdzenie, które padło na początku artykułu. Nowa ewangelizacja to nowa gorliwość w rozgłaszaniu Ewangelii. W tym wypadku to gorliwość kapłanów, którzy są gotowi pospieszyć innym duszpasterzom z pomocą i wielkodusznie dzielą się swym czasem.

Z poruszoną kwestią łączy się potrzeba zmiany modelu księdza duszpasterza związanego wyłącznie z parafią. Podkreślmy jeszcze raz, ewangelizacyjna aktywność w świecie turystyki wymaga wyjścia ewangelizatora ku turyście będącemu w drodze, nie zawsze skłonnego, by przyjść do duszpasterskiego centrum. Szukanie go na szlakach. Toteż konieczna staje się akceptacja działalności kapłanów bardziej

2 Spotyka się np. zwyczaj zastępstwa urlopowego, posługe na statkach turystycznych, episkopaty Niemiec i Austrii organizowały posługę księży w regionach, do których wyjeżdżali turyści z tych krajów; księżą ci spędzali tam zarazem swoje urlopy. 
„mobilnych”. Jest to trudne z różnych powodów, np. braku powołań w Europie, problemów z materialnym zabezpieczeniem, niekiedy konieczności pokonania dotychczasowych przekonań odnośnie funkcjonowania księdza. Z drugiej strony może się okazać, że w niektórych regionach wierni przestaną w ogóle przychodzić do kościoła. I co wtedy, gdy nie wyjdziemy z kościołów, by ich poszukiwać? To wszystko wymaga głębokiej i odpowiedzialnej refleksji zwłaszcza kościelnych przełożonych.

Skoro dotknęliśmy sprawy zmiany modelu kapłana, poruszmy pokrewny problem. Sytuacja turystyki staje się pouczająca dla samego tradycyjnego duszpasterstwa. Współczesny chrześcijanin w wielu regionach Europy coraz mniej jest skłonny przychodzić do parafialnych ośrodków. Duszpasterstwo musi go poszukiwać w miejscach, gdzie żyje, pracuje i wypoczywa. Nie zawsze można liczyć, że on sam wreszcie kiedyś będzie szukał kontaktu z duszpasterzem. W swoim życiu chrześcijanin, zwłaszcza młody, napotyka wiele konkurencyjnych inicjatyw, które odciągają go od tradycyjnych ośrodków i form religijnego życia. Stąd duszpasterstwo winno dostosowywać się do zmienionych okoliczności jego egzystencji. Tu znów wracamy do wymogów nowej ewangelizacji, która jest poszukiwaniem nowych sposobów dróg i sposobów docierania z Ewangelią do człowieka stojącego na obrzeżach.

Wróćmy jednak do głównego wątku. Ważnym ewangelizacyjnym momentem w świecie turystyki jest umiejętne objaśnianie zabytków chrześcijańskiej kultury. To, czy staną się one dla turystów, jak zauważyliśmy, biblia pauperum zależy w dużej mierze od odpowiednio przygotowanych przewodników. Ich objaśnienia mogą stać się prawdziwą ewangelizacją i katechezą, jeśli potrafią wydobyć treści odnoszące się do wiary, ukryte w znakach, objaśnić je, a zwłaszcza powiązać je z życiem turysty. W objaśnieniu nie ograniczą się do ukazania ogólnoludzkich, kulturalnych bądź architektonicznych wartości obiektów sakralnych, lecz pokażą pełną prawdę o ich powstaniu i przeznaczeniu. Rodzi się konieczność odpowiedniej formacji kadry przewodnickiej. Nie chodzi tylko o ich wiedzę, nawet teologiczną, lecz postawę, przez którą staną się świadkami wiary (Ostrowski 1996, 2003).

Skuteczność ewangelizacji poprzez turystykę zależy od wychowania turysty do umiejętności swoistej kontemplacji kultury i przyrody podziwianej podczas wycieczek. Człowiek dzisiejszy jest człowiekiem niespokojnym, nie zawsze zdolnym do dłuższego zatrzymania się i podziwu otaczającej go rzeczywistości. Tymczasem odkrycie Boga w znakach kultury i przyrody nie jest procesem automatycznym, 
wymaga czasu i skupienia. Trzeba zatem uczyć turystyki refleksyjnej, unikającej pośpiechu, przeładowanej nadmiarem wrażeń. Pomagać turyście w wyrabianiu spostrzegawczości i umiejętności koncentracji na obserwowanych podczas wędrówki znakach. Przekonywać, że dążenie do maksimum wrażeń prowadzi do powierzchowności a co za tym idzie nie wykorzystania wszystkich walorów turystyki.

Szansą dla nowej ewangelizacji staje się promowanie turystyki religijnej. Nie wracamy do tego co na temat jej ewangelizacyjnych walorów było powiedziane wcześniej. Dodajmy pastoralną uwagę. Turysta odwiedza podczas wycieczki liczne obiekty sakralne. Kieruje się ciekawością poznania religijnej kultury i sztuki. Można założyć, że jest on osobą wierzącą, albo przynajmniej pozytywnie nastawioną do wiary. Ważną rzeczą jest to, by nie pozostał on na poziomie zaspokajania intelektualnej ciekawości. Uznaje on co prawda, że odwiedzane przez niego obiekty powstały $\mathrm{w}$ religijnych celach i zawierają w sobie wiele znaków wiary. Trzeba jednak umiejętnie przekonywać turystę, iż miejsca te nie są jedynie muzeami i skansenami godnymi podziwu ze względu na piękno architektury, malarstwo, malowniczość położenia itp. Wszystko to co zawierają służy budowaniu ludzkiej wiary. Dziś, teraz miejsca te są ośrodkami życia religijnego, spotkania z Bogiem. To życie w nich pulsuje. Tu dochodzimy do sprawy istotnej z ewangelizacyjnego punktu widzenia. Chodzi o to, by turysta wchodzący w obręb sacrum nie był li tylko zewnętrznym obserwatorem, ale sam stał się skłonny być uczestnikiem trwającego misterium wiary. Ta wiara nie tylko w przenośni powinna rzucić go na kolana. Konsekwencją podejścia z wiarą do świętych miejsc jest modlitwa, więcej adoracja. W ten sposób turysta staje się pielgrzymem - poszukiwaczem Boga.

Oddzielne uwagi należy skierować pod adresem duszpasterstwa w sanktuariach i ośrodkach pielgrzymkowych, które chętnie odwiedzają turyści ze względu na ich kulturowe walory (Parellada 2002). Narastający obok pielgrzymek ruch turystyczny może budzić pewien niepokój. Powstaje zapytanie, czy nie następuje tu niebezpieczeństwo zeświecczenia. Sanktuarium jest miejscem otwartym dla wszystkich. Nie odrzuca nikogo, którego łączy z nim choćby najcieńsza nić. Ma być w myśl kościelnych dokumentów ośrodkiem stale trwającej ewangelizacji. To, że turysta, nawet niewierzący, znalazł się w obrębie świętej przestrzeni, już stanowi szanse intensywniejszego religijnego oddziaływania nań (Ostrowski red. 2003). Jak wskazuje obserwacja wiele kościołów ulegającej laicyzacji Europy wyludnia się. Natomiast proste dane statystyczne wskazują, że rośnie popularność ośrodków pielgrzymkowych. Czy zatem właśnie one nie staną się dla naszego kontynentu ośrodkami religijnej odnowy, re-ewangelizacji? 
Nawiązując do wcześniejszych uwag, ważnym zadaniem sanktuariów jest tworzenie obszarów wyciszenia i skupienia. Współczesny człowiek żyje w coraz większym hałasie i rozproszeniu. Nie sprzyja to bynajmniej rozwojowi osobistego życia religijnego oraz głębszej refleksji nad sensem istnienia. Sanktuarium tworząc tego rodzaju oazy, pełni ważną posługę na rzecz przywracania duchowej równowagi współczesnemu człowiekowi i kierowaniu go w stronę Boga. Stąd też należy postulować funkcjonowanie na terenie sanktuariów kaplic adoracji, miejsc medytacji i domów rekolekcyjnych z dobrze przemyślanym programem formacyjnym.

Artykuł nasz starał się przekonać, iź świat turystyki jest przestrzenią nowej ewangelizacji. Odniósł on szczególnie do sytuacji obserwowanych w Europie. Aby owa ewangelizacja stała się skuteczna trzeba poznać i przekonać się do ewangelicznych wartości niesionych przez turystykę. Z drugiej strony konieczna jest na wielu odcinkach zmiana pastoralnego myślenia i duszpasterskich metod.

\section{Literatura}

Apostolicam actuositatem, Dekret o apostolstwie świeckich, 1965, www.zaufaj.com/ sobor-vaticanum-ii/354.html (12.11.2014).

Constitution on the Sacred Liturgy Sacrosanctum Concilium, 1963, http://www.vatican.va/archive/hist_councils/ii_vatican_council/documents/vatii_const_19631204_ sacrosanctum-concilium_en.html (20.11. 2014).

Gaudium et spes. Konstytucja duszpasterska o Kościele $w$ świecie współczesnym, 1965, http://www.nonpossumus.pl/encykliki/sobor_II/gaudium_et_spes/ (14.11.2014).

Häring B., 1963, Nauka Chrystusa. Teologia moralna szczegółowa, t. 3, Pallotinum, Poznań.

Janik P., 2007, Zdrowie, [w:] A. Muszali (red.), Encyklopedia bioetyki, Wyd. Encyklopedyczne Polwen, Radom, s. 643-644.

Jan Paweł II, 2003, Adhortacja apostolska Ecclesia in Europa, 28 czerwca 2003 r.

Jan Paweł II, 1985, List apostolski do młodych całego świata z okazji Międzynarodowego Roku Młodzieży, z 31 marca 1985 r., Watykan.

Jan Paweł II, 1979, Siła Polaków - osobisty związek z ziemia, homilia w Nowym Targu, 8 czerwca 1979 r., [w:] Jan Pawet na ziemi polskiej, Libreria Editrice Vaticana, Watykan, s. 211-216. 
Ostrowski M., 1996, Duszpasterstwo wobec problemu wolnego czasu człowieka. Aspekt moralno-pastoralny ze szczególnym uwzględnieniem zagadnień turystyki, Wyd. Nauk. PAT, Kraków.

Ostrowski M., 2002, Wallfahrten oder religiöser Tourismus, [w:] Il Santuario, spazio per un'accoglienza fraterna e universale. Atti del 3o Congresso Europeo sui Santuari e i Pellegrinagii, Montserrat, Spagna, 4-7 marzo 2002, Citta del Vaticano 2002, s. 41-51.

Ostrowski M. (red.), 2003, Duszpasterstwo pielgrzymów i turystów. Wybór wypowiedzi i dokumentów kościelnych, Wyd. Św. Stanisława BM, Kraków .

Parellada J. E. 2002, , El ministerio de la acogida, don del Espíritu, [w:] Il Santuario, spazio per un'accoglienza fraterna e universale. Atti del 3o Congresso Europeo sui Santuari e i Pellegrinagii, Montserrat, Spagna, 4-7 marzo 2002, Citta del Vaticano 2002, s. 60-72.

Tourismus im Lichte christlicher Werte, Ansprache in Courmayeur am 7.September 1986, 1986, [w:] Der Apostolische Stuhl. Ansprachen, Predigten und Botschaften des Papstes, Erklärungen der Kongregationen, Vollständige Dokumentation, Köln.

ks. Maciej Ostrowski, prof. dr hab.

Uniwersytet Papieski Jana Pawła II w Krakowie 
